\title{
Cantharidin modulates the E2F1/MCM7-miR-106b-93/p21-PTEN signaling axis in MCF-7 breast cancer cells
}

\author{
HUI ZHANG ${ }^{1}$ and XIULI YAN ${ }^{2}$ \\ ${ }^{1}$ Research Center for Traditional Chinese Medicine Complexity System, Shanghai University of Traditional Chinese Medicine, \\ Shanghai 201203; ${ }^{2}$ Internal Medicine of Traditional Chinese Medicine, \\ Yueyang Hospital of Integrated Traditional Chinese and Western Medicine, \\ Shanghai University of Traditional Chinese Medicine, Shanghai 200437, P.R. China
}

Received October 11, 2014; Accepted August 18, 2015

DOI: $10.3892 / 01.2015 .3681$

\begin{abstract}
Cantharidin (CTD) is one of numerous natural products used in traditional Chinese medicine for the treatment of cancer. The aim of the present study was to investigate the effects of CTD on changes in the expression of microRNAs (miRNAs/miRs) and to explore its anti-proliferative effect on MCF-7 breast cancer cells. The proliferation of MCF-7 cells was measured by performing an MTT assay. MCF-7 cells were treated with various concentrations of CTD for $48 \mathrm{~h}$, and the expression profiles of miRNAs in CTD-treated and -untreated MCF-7 cells were detected using miRNA microarray chips. The array data were confirmed by reverse transcription-quantitative polymerase chain reaction and protein expression levels were measured by western blot analysis. The $50 \%$ inhibitory concentration of CTD was $1.75 \mu \mathrm{g} / \mathrm{ml}$ following treatment for $48 \mathrm{~h}$ and CTD significantly inhibited the proliferation of MCF-7 cells in a dose-dependent manner $(\mathrm{P}<0.01)$. Furthermore, microarray analysis identified 35 miRNAs that were up-regulated (fold change $\geq 2.0$ and $\mathrm{P}<0.01$ ) and 45 miRNAs that were down-regulated (fold change $\leq 0.5$ and $\mathrm{P}<0.01$ ) in response to CTD treatment. Thus, numerous CTD-induced miRNAs appeared to be associated with breast cancer. Notably, CTD repressed the expression of miR-106b-93, its host gene MCM7 and its transcription factor E2F1. In addition, CTD induced an increase in the protein expression levels of miR-106b-93 target genes p21 and phosphatase and tensin homolog. These observations suggested that the modulation of miRNA expression is an important mechanism underlying the biological effects of CTD in breast cancer.
\end{abstract}

Correspondence to: Dr Xiuli Yan, Internal Medicine of Traditional Chinese Medicine, Yueyang Hospital of Integrated Traditional Chinese and Western Medicine, Shanghai University of Traditional Chinese Medicine, 110 Ganhe Road, Hongkou, Shanghai 200437, P.R. China

E-mail: yx19999@126.com

Key words: cantharidin, breast cancer, miRNA, gene regulation

\section{Introduction}

MicroRNAs (miRNAs), non-coding RNAs of 22 nt in length, act as post-transcriptional regulators. miRNAs control mRNA stability and the efficiency of translation by base pairing with complementary sites in the 3'-untranslated region of mRNA (1). The most recent release of miRBase (release 20; http://microrna.sanger.ac.uk/) annotates 2,578 miRNA loci in the human genome (2). A class of these miRNAs has been associated with human cancer (3-6) and are referred to as 'oncomirs' (7). Oncomirs are divided into two groups: i) miRNAs that are upregulated or amplified in cancer and are likely to act as oncogenes; and ii) miRNAs that are deleted or downregulated in cancer and are likely to act as tumor suppressors. Aberrant expression of miRNAs is associated with proliferation (8), invasion (9), apoptosis (10) and signaling pathways (11) in the progression of breast cancer. Considering the association of miRNAs with cancer development and progression, it has been suggested that these small regulatory RNAs serve as potential targets of anticancer therapeutic strategies (12).

Breast cancer is one of the most common types of cancer and has the highest cancer-specific mortality rate in women worldwide (13). It is therefore essential to better understand the underlying molecular mechanisms and to develop novel approaches for the prevention, treatment, and management of breast cancer. Currently, treatment strategy for breast cancer include locoregional treatment with surgery and radiation, plus systemic treatment with chemotherapy, endocrine, and biologic therapies (13). Considering the association of miRNAs with cancer development and progression, it has been suggested that these small regulatory RNAs serve as potential targets of anticancer therapeutic strategies (14).

Cantharidin (CTD) is one of various natural products used in traditional Chinese medicine for the treatment of cancer. CTD can effectively inhibit the proliferation, break the DNA strands of human CCRF-CEM leukemia cells (14), reverse multidrug resistance of hepatoma HepG2/ADM cells (15) and induce apoptosis of human multiple myeloma cells (RPMI-8226, U266, and IM9) (16). However, the exact anti-cancer mechanism of CTD in human cancer cells remains poorly understood. Combined methods of pharmaceutical 
biology and molecular biology may facilitate the elucidation of the modes of action of these natural products.

In the present study, a microarray chip was used for miRNA expression profiling to test our hypothesis that CTD alters miRNA expression profiles in breast cancer cells. The results indicated that CTD alters specific miRNA expression in human breast cancer cells. Furthermore, gene expression that is targeted by these specific miRNAs downregulated by CTD was also modulated by CTD. It therefore appears that miRNA-related changes are an important effect of CTD.

\section{Materials and methods}

Cell culture. MCF-7, MDA-MB-231 and HBL-100 human breast cancer cells were obtained from the American Type Culture Collection (Manassas, VA, USA) and cultured in RPMI-1640 medium (Gibco, San Francisco, CA, USA) supplemented with $10 \%$ heat-inactivated $\left(56^{\circ} \mathrm{C}, 30 \mathrm{~min}\right)$ fetal calf serum (A-4061; PAA Laboratories GmbH, Pasching, Austria), $0.01 \mathrm{mg} / \mathrm{ml}$ insulin (Sigma-Aldrich, St. Louis, MO, USA), 2 mM L-glutamine (Gibco), $100 \mathrm{U} / \mathrm{ml}$ penicillin and $100 \mu \mathrm{g} / \mathrm{ml}$ streptomycin. The cell culture was maintained at $37^{\circ} \mathrm{C}$ in a $5 \% \mathrm{CO}_{2}$ humidified atmosphere.

CTD treatment and cell proliferation assay. MCF-7 cells were seeded in 96-well culture plates $\left(10^{4}\right.$ cells/well). After overnight incubation, various concentrations of CTD (Nanjing Pharmaceutical Factory Co., Ltd., Nanjing China) dissolved in dimethyl sulfoxide (DMSO; Sigma-Aldrich) were added to the plates $(0.0,0.8,1.6,3.2,6.4$ and $12.8 \mu \mathrm{g} / \mathrm{ml})$. DMSO was adjusted to the same final concentration of $0.01 \%$. Following incubation, cell growth was measured by the addition of $20 \mu \mathrm{l}$ $5 \mathrm{~g} / 1$ MTT (Gen-View Scientific, Inc., Calimesa, CA, USA) at $37^{\circ} \mathrm{C}$ for $4 \mathrm{~h}$. DMSO $(150 \mu \mathrm{l})$ was then added to dissolve the formazan crystals. Absorbance was measured at $490 \mathrm{~nm}$ using an enzyme-linked immunosorbent assay plate reader (BioTek, Winooski, VT, USA) to obtain optical density (OD) values. The percentage of inhibition was calculated as: Inhibition ratio $(I R)=\left(1-\mathrm{OD}_{\text {sample }} / \mathrm{OD}_{\text {control }}\right) \times 100 \%$. The $\mathrm{IC}_{50}$ (concentration of CTD required to produce $50 \%$ cell inhibition) was determined and used for subsequent analyses. Experiments were performed in triplicate.

RNA isolation and qualitative detection. Briefly, MCF-7, MDA-MB-231 and HBL-100 cells were collected and washed with cold phosphate-buffered saline. Total RNA was isolated from $5 \times 10^{6}$ cells using $\mathrm{TRIzol}^{\circledR}$ reagent (Invitrogen Life Technologies, Inc., Carlsbad, CA, USA), according to the manufacturer's instructions. Absorbance each RNA sample (MCF-7, MDA-MB-231 and HBL-100 cells) was measured using a NanoDrop 2000 spectrophotometer (ThermoFisher Scientific Inc., Waltham, MA, USA) at wavelengths of 230, 260 and $280 \mathrm{~nm}$, respectively, to determine the purification and concentration of the total RNA samples. The ratio of $28 \mathrm{~S}$ to $18 \mathrm{~S}$ in the total RNA sample was detected by electrophoresis on a $1 \%$ agarose gel containing formaldehyde to evaluate its purification and integrity. RNA samples conforming to the quality requirements (260/230 nm intensity ratio $>1.0$ and $260 / 280 \mathrm{~nm}$ ratio $>1.8$; the $28 \mathrm{~S}$ rRNA band at $4.5 \mathrm{~kb}$ should be twice the intensity of the $18 \mathrm{~S}$ rRNA band at $1.9 \mathrm{~kb}$ ) were used for the microarray assays.
MParaflo ${ }^{T M}$ miRNA microarray assay. A microarray assay was performed using a service provider (LC Sciences, LLC, Houston, TX, USA). A sample of total RNA (5 $\mu \mathrm{g})$ was size-fractionated using a YM-100 Microcon ${ }^{\circledR}$ centrifugal filter (EMD Millipore, Billerica, MA, USA). The isolated small RNAs (<300 nt) were 3'-extended with a polyA polymerase (Invitrogen Life Technologies). An oligonucleotide tag was then ligated to the polyA tail. Hybridization was performed overnight on a $\mu$ Paraflo microfluidic chip using a micro-circulation pump (Atactic Technologies, Houston, TX, USA). On the microfluidic chip containing 723 mature human miRNA probes, each detection probe consisted of a chemically modified nucleotide coding segment complementary to target miRNA from the miRBase Sequence database version 10.0 (Wellcome Trust Sanger Institute, Cambridge, UK; http://microrna.sanger.ac.uk/sequences). The detection probes were constructed by in situ synthesis using photogenerated reagent chemistry. Each probe sequence was repeated five times on the same array chip. The hybridization melting temperatures were balanced by chemical modifications of the detection probes. Hybridization was performed overnight using $100 \mu \mathrm{l}$ 6X SSPE buffer $\left(0.90 \mathrm{M} \mathrm{NaCl}, 60 \mathrm{mM} \mathrm{Na}_{2} \mathrm{HPO}_{4}\right.$, $6 \mathrm{mM}$ EDTA; $\mathrm{pH} 6.8$ ) containing $25 \%$ formamide at $34^{\circ} \mathrm{C}$. Subsequently, hybridization detection was performed by fluorescence labeling using tag-specific $\mathrm{Cy} 3$ and $\mathrm{Cy} 5$ dyes (PerkinElmer, Chalfont, UK). Hybridization images were obtained using a laser scanner [GenePix ${ }^{\circledR}$ 4000B; Molecular Devices, LLC, Sunnyvale, CA, USA] and digitized using Array-Pro image analysis software (Media Cybernetics, Inc., Rockville, MD, USA).

Microarray data handling and analysis. The data were analyzed after subtracting the background and normalizing the signals using a LOWESS filter (locally-weighted regression). For two-color experiments, the ratio of the two sets of detected signals ( $\log _{2}$ transformed, balanced) and P-values of the t-test were calculated. $\mathrm{P}<0.01$ were considered to indicate a statistically significant difference and a fold-change of $\geq 2$ was regarded as statistically significant.

Reverse transcription-quantitative polymerase chain reaction (RT-qPCR) for miRNA analysis. miRNAs, E2F1, MCM7 and GAPDH expression were measured by RT-qPCR. miRNA analysis was performed using a Bulge-Loop ${ }^{\mathrm{TM}}$ miRNA qRT-PCR primer set (Guangzhou RiboBio Co., Ltd., Guangzhou, China), according to the manufacturer's instructions. The U6 small nuclear RNA was used as an internal control for the miRNAs. The mRNA expression of E2F1, MCM7 was normalized to the expression of GAPDH. The relative expression levels were performed with the comparative CT method. Reaction conditions were as follows: $95^{\circ} \mathrm{C}$ for $1 \mathrm{~min}$, followed by 40 cycles of $95^{\circ} \mathrm{C}$ for $15 \mathrm{sec}, 60^{\circ} \mathrm{C}$ for $20 \mathrm{sec}$, and $72^{\circ} \mathrm{C}$ for 15 sec. The primers used for E2F1, MCM7 and GAPDH were as follows: Forward, 5'-CCATCCAGGAAAAGGTGTGAA-3' and reverse, 5'-AGCGCTTGGTGGTCAGATTC-3' for E2F1; forward, 5'-TCTGGCACGTCTGAGAATGGT-3' and reverse, 5'-ACGGACGGTGGCAAATATCA-3' for MCM7; and forward, 5'-AGCCTCAAGATCATCAGCAATG-3' and reverse, 5'-CACGATACCAAAGTTGTCATGGAT-3' for GAPDH. Quantitative expression data were acquired and 
Table I. Effect of cantharidin on miRNA expression in MCF-7 cells.

\begin{tabular}{|c|c|c|}
\hline miRNA name & Fold change & P-value \\
\hline \multicolumn{3}{|l|}{ Upregulated $(n=35)$} \\
\hline hsa-miR-122 & 298.40 & $1.84 \mathrm{E}-06$ \\
\hline hsa-miR-200c & 50.31 & 2.53E-08 \\
\hline hsa-miR-936 & 33.44 & $1.74 \mathrm{E}-05$ \\
\hline hsa-miR-374 ${ }^{\mathrm{a}}$ & 12.16 & $1.81 \mathrm{E}-04$ \\
\hline hsa-miR-214 & 8.43 & 4.43E-03 \\
\hline hsa-miR-149a & 7.90 & $1.05 \mathrm{E}-06$ \\
\hline hsa-miR-637 & 7.73 & $5.46 \mathrm{E}-04$ \\
\hline hsa-miR-654-5p & 7.53 & 3.89E-03 \\
\hline hsa-miR-32a & 7.07 & $6.02 \mathrm{E}-03$ \\
\hline hsa-miR-198 & 6.68 & $1.88 \mathrm{E}-03$ \\
\hline hsa-miR-192 & 5.79 & $1.01 \mathrm{E}-04$ \\
\hline hsa-miR-7 & 5.40 & $2.70 \mathrm{E}-05$ \\
\hline hsa-miR-194 & 4.94 & $1.88 \mathrm{E}-03$ \\
\hline hsa-miR-221 ${ }^{\text {a }}$ & 4.87 & $7.26 \mathrm{E}-03$ \\
\hline hsa-miR-939 & 4.45 & 7.43E-03 \\
\hline hsa-miR-96 & 4.03 & 7.57E-03 \\
\hline hsa-miR-199a-3p & 4.07 & $1.68 \mathrm{E}-03$ \\
\hline hsa-miR-574-5p & 3.91 & $1.81 \mathrm{E}-04$ \\
\hline hsa-miR-98 & 3.86 & $1.70 \mathrm{E}-07$ \\
\hline hsa-miR-483-5p & 3.82 & $1.60 \mathrm{E}-04$ \\
\hline hsa-miR-139-5p & 3.69 & 4.99E-03 \\
\hline hsa-miR-22a & 3.50 & $6.17 \mathrm{E}-05$ \\
\hline hsa-miR-203 & 3.48 & $5.86 \mathrm{E}-03$ \\
\hline hsa-miR-196a & 3.34 & 6.69E-07 \\
\hline hsa-miR-148a & 3.17 & $2.16 \mathrm{E}-03$ \\
\hline hsa-miR-195 & 3.08 & $1.14 \mathrm{E}-03$ \\
\hline hsa-miR-658 & 3.00 & $3.43 \mathrm{E}-05$ \\
\hline hsa-miR-663 & 2.92 & 8.74E-05 \\
\hline hsa-miR-196b & 2.84 & $6.04 \mathrm{E}-05$ \\
\hline hsa-miR-7-1 ${ }^{\text {a }}$ & 2.75 & 2.80E-03 \\
\hline hsa-miR-671-5p & 2.51 & $1.71 \mathrm{E}-04$ \\
\hline hsa-miR-628-5p & 2.50 & $1.72 \mathrm{E}-03$ \\
\hline hsa-miR-34c-3p & 2.39 & $1.86 \mathrm{E}-03$ \\
\hline hsa-miR-638 & 2.30 & $1.10 \mathrm{E}-05$ \\
\hline hsa-miR-574-3p & 2.26 & $1.58 \mathrm{E}-03$ \\
\hline \multicolumn{3}{|c|}{ Downregulated $(\mathrm{n}=45)$} \\
\hline hsa-miR-801 & 0.50 & 8.94E-05 \\
\hline hsa-miR-421 & 0.49 & $7.45 \mathrm{E}-03$ \\
\hline hsa-miR-15a & 0.48 & 4.97E-05 \\
\hline hsa-miR-193a-5p & 0.45 & 9.49E-07 \\
\hline hsa-miR-766 & 0.45 & $1.02 \mathrm{E}-03$ \\
\hline hsa-miR-185 & 0.45 & 2.57E-07 \\
\hline hsa-miR-138 & 0.43 & 2.80E-03 \\
\hline hsa-miR-181b & 0.43 & $7.66 \mathrm{E}-06$ \\
\hline hsa-miR-181a & 0.42 & 1.69E-08 \\
\hline hsa-miR-30d & 0.42 & $1.12 \mathrm{E}-06$ \\
\hline hsa-miR-30a & 0.41 & 4.47E-06 \\
\hline hsa-miR-140-3p & 0.41 & 2.21E-05 \\
\hline hsa-miR-30a ${ }^{a}$ & 0.40 & 4.92E-06 \\
\hline hsa-miR-151-3p & 0.40 & $6.72 \mathrm{E}-07$ \\
\hline
\end{tabular}

Table I. Continued.

\begin{tabular}{|c|c|c|}
\hline miRNA name & Fold change & P-value \\
\hline hsa-miR-500a & 0.38 & 4.61E-04 \\
\hline hsa-miR-505 & 0.38 & $3.65 \mathrm{E}-04$ \\
\hline hsa-miR-532-5p & 0.37 & $6.10 \mathrm{E}-10$ \\
\hline hsa-miR-25a & 0.36 & $2.93 \mathrm{E}-03$ \\
\hline hsa-miR-31 & 0.35 & 4.48E-07 \\
\hline hsa-miR-130b & 0.34 & $1.02 \mathrm{E}-06$ \\
\hline hsa-miR-362-5p & 0.33 & $1.75 \mathrm{E}-06$ \\
\hline hsa-miR-503 & 0.33 & $3.24 \mathrm{E}-06$ \\
\hline hsa-miR-362-3p & 0.33 & $6.24 \mathrm{E}-05$ \\
\hline hsa-miR-93 & 0.32 & $5.39 \mathrm{E}-11$ \\
\hline hsa-miR-30c- $2^{a}$ & 0.32 & $2.08 \mathrm{E}-05$ \\
\hline hsa-miR-423-5p & 0.32 & $5.78 \mathrm{E}-07$ \\
\hline hsa-miR-193b & 0.31 & $2.28 \mathrm{E}-04$ \\
\hline hsa-miR-106b & 0.31 & $9.36 \mathrm{E}-08$ \\
\hline hsa-miR-744 & 0.30 & $4.02 \mathrm{E}-06$ \\
\hline hsa-miR-324-5p & 0.29 & $4.05 \mathrm{E}-07$ \\
\hline hsa-miR-378 & 0.28 & $1.76 \mathrm{E}-06$ \\
\hline hsa-miR-455-3p & 0.28 & 4.37E-09 \\
\hline hsa-miR-103 & 0.28 & $1.02 \mathrm{E}-08$ \\
\hline hsa-miR-18b & 0.27 & 7.63E-05 \\
\hline hsa-miR-107 & 0.27 & $5.78 \mathrm{E}-08$ \\
\hline hsa-miR-550 & 0.26 & 2.32E-08 \\
\hline hsa-miR-877 & 0.25 & 2.93E-04 \\
\hline hsa-miR-425 & 0.24 & $5.74 \mathrm{E}-08$ \\
\hline hsa-miR-484 & 0.22 & 4.01E-05 \\
\hline hsa-miR-34a & 0.21 & $6.82 \mathrm{E}-08$ \\
\hline hsa-miR-99b & 0.20 & $3.58 \mathrm{E}-08$ \\
\hline hsa-miR-18a & 0.18 & $4.57 \mathrm{E}-08$ \\
\hline hsa-miR-197 & 0.16 & $1.29 \mathrm{E}-08$ \\
\hline hsa-miR-186 & 0.04 & $3.28 \mathrm{E}-08$ \\
\hline hsa-miR-542-5p & 0.02 & $1.51 \mathrm{E}-04$ \\
\hline
\end{tabular}

analyzed using a LightCycler 1.5 Instrument (Roche Applied Science, Indianapolis, IN, USA).

Transient miRNA transfection. MCF-7 cells at 50\% confluency were transfected with miR-Ribo ${ }^{\mathrm{TM}} \mathrm{miR}-106 \mathrm{~b}$ inhibitor and negative control inhibitor (Guangzhou RiboBio Co., Ltd.) to a final concentration of $100 \mathrm{nmol} / \mathrm{l}$ with Lipofectamine ${ }^{\mathrm{TM}}$ 2000 transfection reagent (Invitrogen Life Technologies, Inc.), according to the manufacturer's instructions. After $6 \mathrm{~h}$ of transfection, the cells were placed in complete medium and maintained at $37^{\circ} \mathrm{C}$ in a $5 \% \mathrm{CO}_{2}$ atmosphere. Following $48 \mathrm{~h}$ of transfection, and RNA was harvested using TRIzol reagent (BioDev-Tech Co., Beijing, China).

Western blot analysis. Briefly, cell pellets were resuspended in lysis buffer containing $2 \mathrm{M}$ sodium chloride, $10 \% \mathrm{NP}-40$, $10 \%$ SDS, $1 \mathrm{M} / 1$ Tris-Cl, $1 \mathrm{~g} / 1$ phenyl-methylsulfonyl fluoride, $0.1 \mathrm{~g} / 1$ aprotinin and $0.01 \mathrm{~g} / 1$ leupeptin, and incubated at $4^{\circ} \mathrm{C}$ 


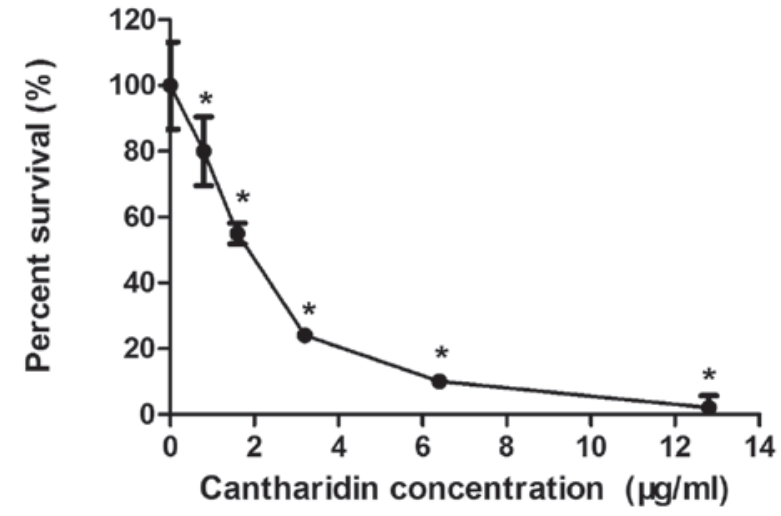

Figure 1. Cantharidin significantly inhibits the proliferation of MCF-7 cells. The effect of cantharidin on MCF-7 cell proliferation was determined by performing an MTT assay. Absorbance was measured at $490 \mathrm{~nm}$ and expressed as cell survival relative to the untreated control. Results are presented as the mean \pm standard deviation of three independent experiments ( $\mathrm{P}<0.01)$.

for $30 \mathrm{~min}$. After $13,400 \mathrm{x} \mathrm{g}$ centrifugation for $5 \mathrm{~min}$ at $4^{\circ} \mathrm{C}$, the protein content of the supernatant was determined using a protein assay reagent (Bio-Rad Laboratories, Inc., Hercules, CA, USA). Proteins were separated on a $10 \%$ SDS-PAGE gel and blotted onto polyvinylidene difluoride membrane. The membrane was blocked with bovine serum albumin for $\sim 1 \mathrm{~h}$ at room temperature. The protein expression was detected using primary antibody [p21, cat no. 2946 and phosphatase and tensin homolog (PTEN), cat no. 9559S; 1:1000 dilution; Cell Signaling Technology, Inc., Beverly, MA, USA] and secondary antibody (1:800 dilution) conjugated with horseradish peroxidase, followed by treatment with electrochemiluminescence reagents (GE Healthcare, Amersham, UK). Images of the western blot films were acquired using AlphaEase ${ }^{\mathrm{TM}}$ (Alpha Innotech Corporation, CA, USA) and FluorChem ${ }^{\mathrm{TM}} \mathrm{FC} 2$ software (Medford, NJ, USA).

Statistical analysis. Data were presented as the mean \pm standard deviation. Comparisons between groups were performed by using the Student's t-test and the statistical analyses were performed using SPSS software (version 19.0; IBM SPSS, Armonk, NY, USA). Tests were two-tailed and $\mathrm{P}<0.01$ was considered to indicate a statistically significant difference.

\section{Results}

CTD treatment inhibits the proliferation of MCF-7 cells. The MTT assay was used to determine the effects of CTD on MCF-7 human breast cancer cell growth. Fig. 1 shows the effects of $0.8-12.8 \mu \mathrm{g} / \mathrm{ml} \mathrm{CTD}$ on the growth of MCF-7 cells. After $48 \mathrm{~h}$ of incubation, CTD significantly inhibited the proliferation of MCF-7 cells in a dose-dependent manner $(\mathrm{P}<0.01)$. Treatment with CTD concentrations of $0.8 \mu \mathrm{g} / \mathrm{ml}$ compared with $12.8 \mu \mathrm{g} / \mathrm{ml}$ resulted in a reduction in cell numbers from $98 \pm 4$ to $20 \pm 7 \%$. The $\mathrm{IC}_{50}$ of CTD was $1.75 \mu \mathrm{g} / \mathrm{ml}$ following treatment for $48 \mathrm{~h}$. Thus, a dose of $1.75 \mu \mathrm{g} / \mathrm{ml} \mathrm{CTD}$ was used as the therapeutic drug concentration in all subsequent experiments.

CTD treatment alters miRNA expression profiles. To assess whether miRNA expression responds to CTD treatment in breast cancer, microarray analysis was conducted with

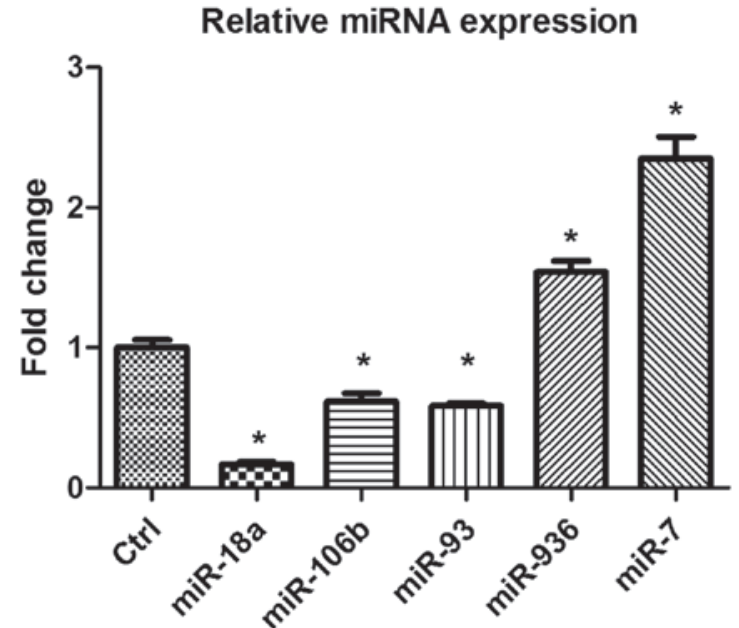

Figure 2. Confirmatory expression of selected miRNAs by reverse transcription-quantitative polymerase chain reaction. The fold changes refer to the expression fold changes of the selected miRNAs in cantharidin-treated cells compared with the untreated Ctrl cells. The results are presented as the mean \pm standard deviation of three independent experiments $\left({ }^{*} \mathrm{P}<0.01\right)$. U6 was used as internal control. miRNA/miR, microRNA; Ctrl, control.

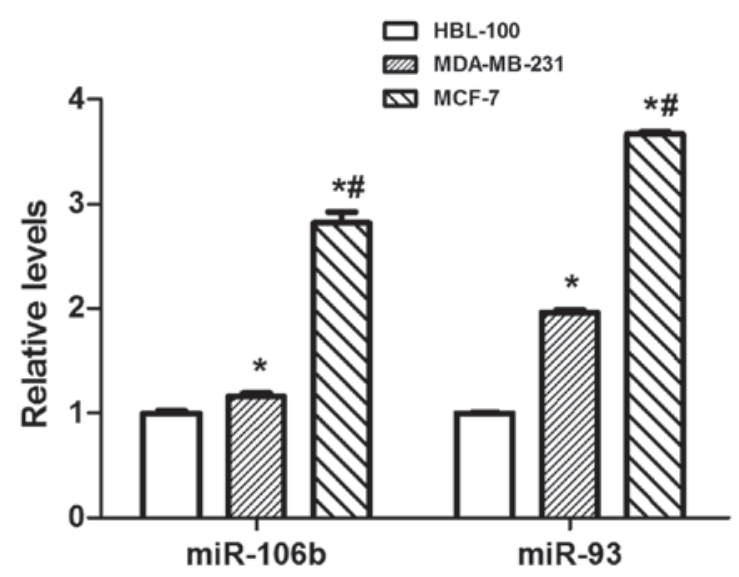

Figure 3. miR-106b-93 expression in MCF-7, MDA-MB-231 and HBL-100 cells. The fold changes refer to the expression fold changes of the miR-106b-93 in MCF-7 and MDA-MB-231 cells compared with HBL-100 cells. The results are presented as the mean \pm standard deviation of three independent experiments ( $\mathrm{P}<0.01$ vs. HBL-100; ${ }^{\#} \mathrm{P}<0.01$ vs. MDA-MB-231). GAPDH was used as internal control. miR, microRNA.

miRNA-enriched total RNAs isolated from MCF-7 cells treated with $1.75 \mu \mathrm{g} / \mathrm{ml} \mathrm{CTD}$ for $48 \mathrm{~h}$. RNA samples were processed, labeled and hybridized to miRNA chips, as described in Materials and methods. According to the microarray-based screening, changes in miRNA expression were observed between CTD-treated cells and untreated control cells. Compared with the control group, Table I indicates that there were 80 differentially expressed miRNAs in the CTD-treated group. Of these, 35 miRNAs were significantly upregulated and 45 miRNAs were significantly downregulated $(\mathrm{P}<0.01)$. A greater number of miRNAs were downregulated than upregulated following CTD treatment.

Validation of microarray results by $R T-q P C R$. To validate the microarray data, miR-18a, miR-106b, miR-93, miR-936 and miR-7 were selected at random and their expression levels 
Relative MCM7 and E2F1 expression

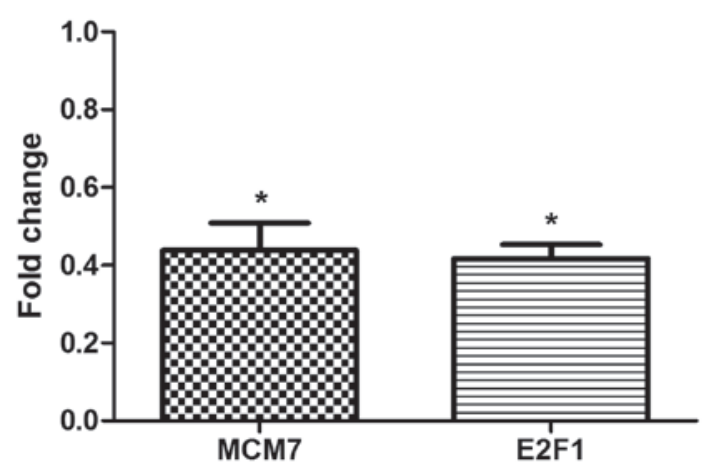

Figure 4. Cantharidin significantly inhibits the expression of MCM7 and E2F1 in cantharidin-treated cells compared with the Ctrl cells. The results are presented as the mean \pm standard deviation of three independent experiments ( $\mathrm{P}<0.01)$. Ctrl, control.

A Relative miR-106b expression

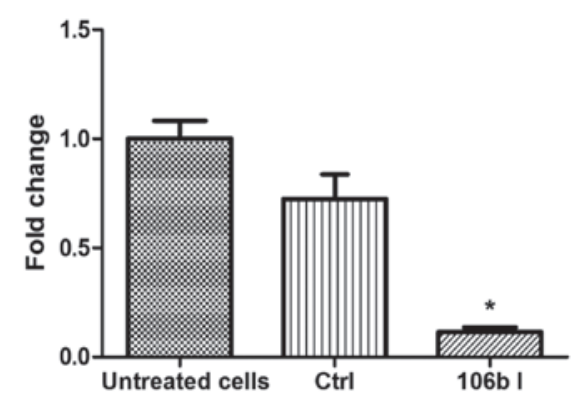

B

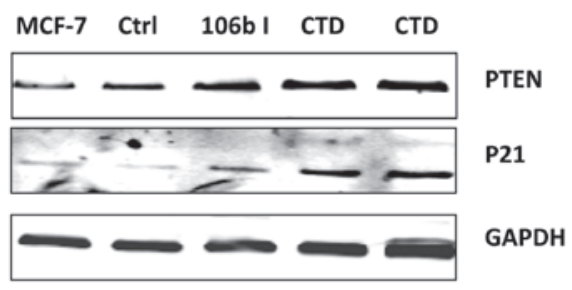

Figure 5. CTD upregulates the expression of PTEN and p21. MCF-7 cells were transfected with $100 \mathrm{nM}$ negative Ctrl inhibitor and 106b I. miR-106b levels were analyzed by (A) reverse transcription-quantitative polymerase chain reaction and (B) western blotting $48 \mathrm{~h}$ after transfection. CTD upregulated the expression of PTEN and p-21 proteins. ${ }^{*} \mathrm{P}<0.01$ vs. MCF-7 cells. miR, microRNA; Ctrl, negative control inhibitors; 106b I, miR-106b inhibitor; CTD, cantharidin.

were assayed by RT-qPCR. The results from the microarray and RT-qPCR were compared. Of the miRNAs selected for comparison, two miRNAs (miR-936 and miR-7) were significantly upregulated and three miRNAs (miR-106b, miR-93 and miR-18a) were significantly downregulated compared with the untreated control cells based on the results of microarray analysis $(\mathrm{P}<0.01)$. The expression data obtained by RT-qPCR analysis are comparable to the microarray analysis data, although miR-936 was upregulated to a lesser degree in the RT-qPCR analysis (Fig. 2).

CTD treatment downregulates the expression of the miR-106b-93 host gene MCM7 and its transcription factor E2F1 in MCF-7 cells. miR-106b-93 are aberrantly overexpressed in numerous types of human cancer (18-21). Therefore, miR-106b-93 expression was detected in MCF-7, MDA-MB-231 and HBL-100 cells, and it was identified that miR-106b-93 expression is significantly elevated in MCF-7 breast cancer cells compared with MDA-MB-231 and HBL-100 cells $(\mathrm{P}<0.01$; Fig. 3$)$. To demonstrate the effect of CTD on the expression of miR-106b-93, host gene MCM7 and its transcription factor E2F1, qPCR was performed following $48 \mathrm{~h}$ of CTD treatment. The results demonstrated a significant reduction in MCM7 and E2F1 expression following CTD treatment compared with the untreated control cells $(\mathrm{P}<0.01$; Fig. 4).

$C T D$ represses miR-106b-93 expression and induces the protein expression of its targets p21 and PTEN. To demonstrate the effect of CTD on miR-106b-93 target genes p21 and PTEN, western blot analysis was performed following 48 h CTD treatment. p21 and PTEN have been shown to be miR-106b and miR-93 post-transcriptional targets $(18,20,22)$. MCF-7 cells exhibited a significant reduction in E2F1, MCM7, miR-106b and miR-93 expression following CTD treatment $(\mathrm{P}<0.01$; Figs. 2 and 4). Following confirmation of miR-106b inhibition (Fig. 5A), p21 and PTEN protein expression were observed to be increased in MCF-7 cells treated with CTD (Fig. 5B). These results suggested that CTD inhibits miR-106b and miR-93 expression, and functions in breast cancer, as indicated by a reduction of its targets, p21 and PTEN, which are important tumor suppressors in breast cancer.

\section{Discussion}

miRNAs are small regulatory RNA molecules that modulate the expression levels of specific target genes (17). miRNAs function in transcriptional and post-transcriptional regulation of gene expression; for example, acting as transcription factors (18). In cancer, miRNAs function as regulatory molecules, serving as oncogenes or tumor suppressors. Thus, miRNAs may serve as novel therapeutic targets in cancer (19).

CTD is one of numerous natural products used in traditional Chinese medicine for the treatment of cancer. Previous studies have demonstrated that CTD has potent growth-inhibitory and proapoptotic effects on cancer. These effects may be mediated through any of the various mechanisms via which CTD interferes with cell signaling (14-16). However, the molecular basis of the effects of CTD remains to be elucidated. In the present study, the potential modulation of miRNA by CTD was explored. A microarray chip was used to investigate whether CTD alters miRNA expression profiles. It was determined that the expressions of 80 miRNAs (fold change, $\geq 2$; $\mathrm{P}<0.01)$ were regulated by CTD exposure in MCF-7 cells. By performing a search of the literature on Pubmed, the present study identified that numerous breast cancer-related miRNAs were significantly affected by CTD exposure. For example, previous studies determined that the expressions of miR-7, miR-195, miR-203 and miR-214 tumor suppressors were downregulated in human breast cancer (20-23). In the present study, miR-7, miR-195, miR-203 and miR-214 were significantly upregulated in MCF-7 breast cancer cells following treatment with CTD. Similarly, the expression of miR-93, 
miR-106b and miR-378 were significantly downregulated by CTD and upregulated in human breast cancer $(24,25)$. Thus, CTD-induced miRNAs exhibit anti-tumor activity against breast cancer.

miR-106b-93, which reside in the thirteenth intron of the $M C M 7$ gene (chromosome 7), is overexpressed in various types of cancer, including breast (24), hepatocellular (26), gastric (27), and head and neck squamous cell (28) carcinomas, acting as an oncogene. miR-106b-93 are considered to be important in cancer progression by targeting tumor suppressor genes CDKNIA (p21) and PTEN (27,29). Furthermore, miR-106b-93 are activated by E2F1 in parallel with its host gene, MCM7 (30). In turn, miR-106b and miR-93 regulate E2F1 expression, establishing a miRNA negative feedback loop (30). E2F1 functions as an oncogenic transcription factor to promote breast cancer cell proliferation and its expression has been observed to be significantly increased in breast cancer (31). In the present study, it was identified that MCF-7 cells exhibit a significant reduction in E2F1, MCM7, miR-106b and miR-93 expression following CTD treatment (Figs. 2 and 4). Furthermore, the protein expression of miR-106b-93 target genes $p 21$ and PTEN were markedly increased in MCF-7 cells following CTD treatment (Fig. 5). These results indicate that CTD decreases transcription factor E2F1 levels, represses the transactivation of the MCM7 gene, miR-106b-93 expression, and enhances the expression of the miR-106b-93 targets p21 and PTEN.

In conclusion, increasing evidence indicates the role of miRNAs as oncogenes and/or tumor suppressor genes within the gene regulatory networks. The contribution of miRNAs to the development of cancer has significant implications in the future of personalized medicine and cancer treatment. For example, miRNAs may serve as diagnostic and prognostic markers, therapeutic targets or tools in cancer diagnosis and treatment. The present study identified a significant upregulation of tumor-suppressing miRNAs and a significant downregulation of oncogenic miRNAs following CTD treatment of MCF-7 cells. In particular, CTD may affect the E2F1/MCM7-miR-106b-93/p21-PTEN signaling pathway. This result suggests an important and novel mechanism by which CTD mediates its potent effects on cell growth and proliferation. However, the results obtained in this study remain to be verified in future investigations.

\section{Acknowledgements}

The present study was supported by the National Natural Science Foundation of China (no. 81373518), as well as grants from the Doctoral Fund of Ministry of Education of China (grant no. 20093107120010) and Xinglin Scholars Projects of Shanghai University of Traditional Chinese Medicine (grant nos. R13010109 and A1-20141009).

\section{References}

1. Filipowicz W, Bhattacharyya SN and Sonenberg N: Mechanisms of post-transcriptional regulation by microRNAs: Are the answers in sight?. Nat Rev Genet 9: 102-114, 2008.

2. Griffiths-Jones S, Saini HK, van Dongen S and Enright AJ: miRBase: Tools for microRNA genomics. Nucleic Acids Res 36: D154-D158, 2008.
3. Johnson SM, Grosshans H, Shingara J, Byrom M, Jarvis R, Cheng A, Labourier E, Reinert KL, Brown D and Slack FJ: RAS is regulated by the let-7 microRNA family. Cell 120: 635-647, 2005.

4. Bonci D, Coppola V, Musumeci M, Addario A, Giuffrida R, Memeo L, D'Urso L, Pagliuca A, Biffoni M, Labbaye C, et al: The miR-15a-miR-16-1 cluster controls prostate cancer by targeting multiple oncogenic activities. Nat Med 14: 1271-1277, 2008.

5. Si ML, Zhu S, Wu H, Lu Z, Wu F and Mo YY: MiR-21-mediated tumor growth. Oncogene 26: 2799-2803, 2007.

6. Lee DY,DengZ, Wang CHand Yang BB: MicroRNA-378 promotes cell survival, tumor growth and angiogenesis by targeting $\mathrm{SuFu}$ and Fus-1 expression. Proc Natl Acad Sci USA 104: 20350-20355, 2007.

7. Esquela-Kerscher A and Slack FJ: Oncomirs: microRNAs with a role in cancer. Nat Rev Cancer 6: 259-269, 2006.

8. Hossain A, Kuo MT and Saunders GF: Mir-17-5p regulates breast cancer cell proliferation by inhibiting translation of AIB1 mRNA. Mol Cell Biol 26: 8191-8201, 2006.

9. Ma L, Teruya-Feldstein J and Weinberg RA: Tumour invasion and metastasis initiated by microRNA-10b in breast cancer. Nature 449: 682-688, 2007.

10. Frankel LB, Christoffersen NR, Jacobsen A, Lindow M, Krogh A and Lund AH: Programmed cell death 4 (PDCD4) is an important functional target of the microRNA miR-21 in breast cancer cells. J Biol Chem 283: 1026-1033, 2007.

11. Wang $\mathrm{V}$ and $\mathrm{Wu} \mathrm{W}$ : MicroRNA: A new player in breast cancer development (Review). Cancer Mol 3: 133-138, 2007.

12. Liu G, Wong-Staal F and Li QX: Development of new RNAi therapeutics. Histol Histopathol 22: 211-217, 2007.

13. Miller BA, Chu KC, Hankey BF and Ries LA: Cancer incidence and mortality patterns among specific Asian and pacific islander populations in the U.S. Cancer Causes Control 19: 227-256, 2008.

14. Efferth T, Rauh R, Kahl S, Tomicic M, Böchzelt H, Tome ME, Briehl MM, Bauer R and Kaina B: Molecular modes of action of cantharidin in tumor cells. Biochem Pharmacol 69: 811-818, 2005.

15. Zheng LH, Bao YL, Wu Y, Yu CL, Meng X and Li YX: Cantharidin reverses multidrug resistance of human hepatoma HepG2/ADM cells via down-regulation of P-glycoprotein expression. Cancer Lett 272: 102-109, 2008.

16. Sagawa M, Nakazato T, Uchida H, Ikeda Y and Kizaki M: Cantharidin induces apoptosis of human multiple myeloma cells via inhibition of the JAK/STAT pathway. Cancer Sci 99: 1820-1826, 2008.

17. Shivdasani RA: MicroRNAs: Regulators of gene expression and cell differentiation. Blood 108: 3646-3653, 2006.

18. Ross JS, Carlson JA and Brock G: miRNA: The new gene silencer. Am J Clin Pathol 128: 830-836, 2007.

19. Chen CZ: MicroRNAs as oncogenes and tumor suppressors. N Engl J Med 353: 1768-1771, 2005.

20. Reddy SD, Ohshiro K, Rayala SK and Kumar R: MicroRNA-7, a homeobox D10 target, inhibits p21-activated kinase 1 and regulates its functions. Cancer Res 68: 8195-8200, 2008.

21. Li D, Zhao Y, Liu C, Chen X, Qi Y, Jiang Y, Zou C, Zhang X, Liu S, Wang X, et al: Analysis of MiR-195 and MiR-497 expression, regulation and role in breast cancer. Clin Cancer Res 17: 1722-1730, 2011.

22. Wang C, Zheng X, Shen C and Shi Y: MicroRNA-203 suppresses cell proliferation and migration by targeting BIRC5 and LASP1 in human triple-negative breast cancer cells. J Exp Clin Cancer Res 31: 58, 2012.

23. Derfoul A, Juan AH, Difilippantonio MJ, Palanisamy N, Ried T and Sartorelli V: Decreased microRNA-214 levels in breast cancer cells coincides with increased cell proliferation, invasion and accumulation of the Polycomb Ezh2 methyltransferase. Carcinogenesis 32: 1607-1614, 2011.

24. Ivanovska I, Ball AS, Diaz RL, Magnus JF, Kibukawa M, Schelter JM, Kobayashi SV, Lim L, Burchard J, Jackson AL, et al: MicroRNAs in the miR-106b family regulate p21/CDKN1A and promote cell cycle progression. Mol Cell Biol 28: 2167-2174, 2008.

25. Feng $\mathrm{M}$, Li $\mathrm{Z}$, Aau $\mathrm{M}$, Wong $\mathrm{CH}$, Yang $\mathrm{X}$ and $\mathrm{Yu} \mathrm{Q}$ : Myc/miR-378/TOB2/cyclin D1 functional module regulates oncogenic transformation. Oncogene 30: 2242-2251, 2011.

26. Li Y, Tan W, Neo TW, Aung MO, Wasser S, Lim SG and Tan TM: Role of the miR-106b-25 microRNA cluster in hepatocellular carcinoma. Cancer Sci 100: 1234-1242, 2009. 
27. Kan T, Sato F, Ito T, Matsumura N, David S, Cheng Y, Agarwal R, Paun BC, Jin Z, Olaru AV, et al: The miR-106b-25 polycistron, activated by genomic amplification, functions as an oncogene by suppressing p21 and Bim. Gastroenterology 136: 1689-1700, 2009.

28. Hui AB, Lenarduzzi M, Krushel T, Waldron L, Pintilie M, Shi W, Perez-Ordonez B, Jurisica I, O'Sullivan B, Waldron J, et al: Comprehensive MicroRNA profiling for head and neck squamous cell carcinomas. Clin Cancer Res 16: 1129-1139, 2010.

29. Poliseno L, Salmena L, Riccardi L, Fornari A, Song MS Hobbs RM, Sportoletti P, Varmeh S, Egia A, Fedele G, et al: Identification of the miR-106b 25 microRNA cluster as a proto-oncogenic PTEN-targeting intron that cooperates with its host gene MCM7 in transformation. Sci Signal 3: ra29, 2010.
30. Petrocca F, Visone R, Onelli MR, Shah MH, Nicoloso MS, de Martino I, Iliopoulos D, Pilozzi E, Liu CG, Negrini M, et al: E2F1-Regulated MicroRNAs impair TGFbeta-dependent cell-cycle arrest and apoptosis in gastric cancer. Cancer Cell 13: 272-286, 2008

31. Han S, Park K, Bae BN, Kim KH, Kim HJ, Kim YD and Kim HY: E2F1 expression is related with the poor survival of lymph node-positive breast cancer patients treated with fluorouracil, doxorubicin and cyclophosphamide. Breast Cancer Res Treat 82: 11-16, 2003. 